\title{
INOVASI PERANCANGAN MOTIF TIE-DYE (IKAT CELUP) DI KOTA YOGYAKARTA
}

\author{
Sugeng Wardoyo dan Suryo Tri Widodo *)
}

\begin{abstract}
The existence of tie-dye in Yogyakarta city as a craft products has promised prospect. Uniqueness of tie-dye compare with another crafts textiles is in processes making which is simple to result a motifs on to the fabric are faster and easier to learn about. As a tourism city, Yogyakarta has potential to develop tie-dye also as a good place to produce and market tie-dye products. So inovation in designing new tie-dye motifs become positive step, because demand tie-dye products in market rapidly, beside always on dynamic market.
\end{abstract}

Keywords: Craft textiles, Textile motifs, Tie-dye, Jumputan Yogyakarta

\begin{abstract}
PENDAHULUAN
Eksistensi kerajinan tie-dye khususnya di kota Yogyakarta sudah lumayan baik. Meskipun kepopulerannya masih di bawah bayang-bayang maraknya keberadaan batik, namun sebenarnya tiedye memiliki prospek dan potensi pasar yang cukup menjanjikan. Dikatakan masih di bawah bayang-bayang batik karena pemahaman masyarakat awam tentang tiedye juga belum begitu memasyarakat seperti halnya pemahaman mereka mengenai batik. Hal ini dikarenakan tie-dye sendiri pada dasarnya memiliki kesamaan teknik dengan batik, yaitu teknik pembuatannya dengan metode resist-dye (celup rintang), sehingga seringkali masyarakat awam keliru menyebut tie-dye dengan sebutan batik.
\end{abstract}


dye juga cukup banyak yang menggemarinya karena harganya yang relatif murah meriah, sehingga dapat terjangkau oleh berbagai lapisan masyarakat.

Sebagai kota tujuan wisata, Yogyakarta dipandang memiliki potensi yang cukup baik bagi perkembangan tiedye, di samping juga merupakan salah satu kota tempat produksi dan pemasaran tiedye yang cukup potensial. Hal tersebut dapat terlihat dari cukup banyaknya berbagai jenis produk tie-dye dengan harga relatif terjangkau yang dipasarkan di sini, terlihat di dua lokasi objek wisata utama yang cukup dikenal, yaitu di sepanjang kawasan jalan Malioboro dan Pasar Beringharjo Yogyakarta. Sejauh ini produkproduk yang dihasilkan juga sudah cukup bervariasi, namun potensi ini belum tersentuh secara khusus untuk dikembangkan secara lebih lanjut. Potensi pasar bagi produk tie-dye apabila dikaitkan dengan potensi kepariwisataan di wilayah kota Yogyakarta sangatlah mendukung, apalagi Yogyakarta memiliki predikat sebagai kota tujuan wisata terbesar kedua setelah Bali. Langkah strategis yang dapat dilakukan untuk mengantisipasi sekaligus mengatasi agar produk tie-dye yang diproduksi dapat menjawab selera pasar yang dinamis sehingga mampu memiliki daya saing produk yang diperhitungkan terutama di era pasar global seperti sekarang ini, adalah dengan melakukan upaya terobosan melalui perancangan motif tie-dye yang inovatif. $\mathrm{Hal}$ ini merupakan sebuah langkah dan upaya yang kongkret guna mengangkat nilai tambah khususnya bagi para perajin di wilayah ini.
Berkaitan dengan hal tersebut di atas, maka artikel ini diarahkan untuk lebih memperkenalkan, menggali, dan menjelaskan mengenai peluang atau potensi dalam mengembangkan berbagai motif tie-dye. Hal ini dipandang penting dilakukan dengan harapan hasilnya nanti dapat diaplikasikan oleh para perajin tie-dye khususnya dalam skala usaha kecil dan menengah, guna meningkatkan nilai ekonomi mereka.

Nian S. Djoemena dalam Batik dan Mitra: Batik and Its Kind, menguraikan tentang berbagai macam kain tie-dye yang ada di berbagai wilayah Indonesia. Dijelaskan oleh Djoemena, bahwa di daerah Yogyakarta dan Jawa Tengah, kain tie-dye ada yang disebut dengan tritik, yaitu menerapkan keteknikan yang disebut stitch (jahit) dengan teknik jahit jelujur. Di samping tritik ada kain tie-dye yang disebut dengan jumputan dan pelangi. Jumputan merupakan teknik ikat (tie), dengan cara kain dicomot atau ditarik atau dijumput (bhs. Jawa), untuk kemudian diikat dengan tali, di mana bagian yang tidak diberi warna akan tetap berwarna putih. Pelangi pada hakekatnya merupakan kain jumputan dengan ciri khas tata warna dan ragam hias yang lebih bervariasi, kadang-kadang dikombinasikan dengan teknik tritik. Pemberian nama pelangi ini kemungkinan juga untuk menyebut keanekaragaman gradasi warna yang diterapkan di dalamnya. Di luar Jawa, kain-kain tie-dye juga cukup dikenal seperti di daerah Bali, Lombok, Palembang, Sulawesi, dan Kalimantan yang dikenal dengan kain tie-dye yang disebut dengan sasirangan (Djoemena, 1990: 90101). Secara garis besar, pokok bahasan dalam buku ini memperbincangkan mengenai berbagai macam kain tie-dye 
tradisional yang ada di Indonesia, dengan kajian yang masih bersifat umum dan belum menyentuh esensi permasalahan dari aspek pengembangan motifnya.

Pengkajian menarik lainnya mengenai tie-dye dapat dibaca dalam Shibori: The Inventive Art of Japanese Shaped Resist Dyeing: Tradition Techniques Inovation. Buku ini secara khusus mengulas mengenai keberadaan tie-dye di Jepang yang dikenal dengan sebutan shibori dari berbagai aspek kajian. Dibeberkan bahwa keteknikan-keteknikan dasar dalam tie-dye merupakan sebagian kecil dari keteknikan shibori yang dikenal di Jepang (Wada, Kellogg Rice, and Barton, 1999). Buku ini meskipun secara khusus hanya menyoroti kain-kain tie-dye Jepang yang disebut shibori, namun sangat menarik dari sisi pembahasan mengenai pelbagai keteknikan dalam tie-dye, sehingga layak diacu sebagai tuntunan awal dalam pelaksanaan penelitian ini.

Dalam Batik The Art and Craft diilustrasikan bahwa di samping keteknikan batik, ada teknik lain dalam proses pembuatan motif di atas kain yang disebut dengan tie-dye. Prinsip dasar dalam pembuatan tie-dye adalah dengan penerapan proses dan teknik pewarnaan yang hampir sama dengan proses pewarnaan pada batik. Dalam buku ini diuraikan juga beberapa keteknikan tie dye. Diperinci lebih lanjut di dalamnya, bahwa teknik dalam tie-dye tidak sebatas pada teknik ikat (tie) saja, namun juga dikenal teknik lain seperti lipat (pleat) dan jahit (stitch) (Keller, 1971).

Penelitian mengenai tie-dye juga pernah dilakukan oleh Joannifer Gibbs, yang kemudian dituangkannya dalam buku yang diberi judul Batik Unlimited. Dalam buku ini diuraikan oleh Gibbs beberapa contoh keteknikan dalam pembuatan tie-dye, termasuk berbagai aspek potensi pengembangannya. Dijabarkan bahwa keteknikan dalam tie-dye sangat dimungkinkan adanya temuan-temuan baru tanpa batas, dalam upaya menghasilkan motif-motif baru yang unik dan menarik (Gibbs, 1974). Buku ini sangat bermanfaat kaitannya dengan beberapa poin yang dapat didalami guna perancangan motif-motif tie-dye yang baru.

Penelitian dalam bentuk skripsi yang disusun oleh Suryo Tri Widodo yang diberi judul "Kriya Tekstil Tie-dye di ARIMBI Fashion Design \& Exclusive Production Tie \& Dye," dapat dijadikan titik tolak dan tolok ukur bagi penelitian ini. Skripsi ini meskipun hanya mengulas mengenai salah satu produsen atau perajin tie-dye yang eksis di kota Yogyakarta, namun di dalamnya sudah terdapat uraian cukup panjang lebar mengenai pengembangan motif tie-dye dari berbagai keteknikan dasar yang sudah ada sebelumnya (Widodo, 1998). Oleh karena itu beberapa hasil tulisan dan rumusan temuan dalam skripsi tersebut dapat dijadikan referensi dasar bagi pelaksanaan penelitian ini.

Penelitian tentang tie-dye khususnya di wilayah kota Yogyakarta juga pernah dilakukan. Penelitian tersebut diberi judul "Pengembangan Teknik dan Motif Pada Produk Tie-Dye (Ikat Celup) di Kota Yogyakarta." Penelitian ini berhasil memetakan informasi penerapan berbagai teknik dan motif pada produk tie-dye khususnya yang dipasarkan di Kota 
Yogyakarta (Widodo, 2010). Hal ini sangat mendukung dan sejalan dengan tujuan dari usulan penelitian ini. Namun sayangnya penelitian yang telah dilaksanakan tersebut belum ditindaklanjuti secara lebih jauh. Oleh karena itu, beberapa temuan dan hasil kajian yang telah dilakukan tersebut dapat dimanfaatkan secara lebih mendalam lagi dalam penelitian ini.

Sebuah artikel dalam jurnal ilmiah Corak: Jurnal Seni Kriya dengan judul "Kriya Tekstil Tie-Dye (Ikat Celup): Sebuah Media eksplorasi Estetis yang Populer," memberikan sebuah panduan dasar sekaligus menawarkan beberapa peluang dalam pengembangan motif tie-dye. Isi dalam artikel ini memuat seluk-beluk keberadaan sekaligus berbagai jenis teknik tie-dye dari beberapa wilayah di Indonesia termasuk dari luar. Pembahasan juga memuat mengenai teknik-teknik dasar dalam tie-dye yang berpotensi untuk dikembangkan lagi secara lebih lanjut (Widodo, 2012). Tulisan ini dapat diposisikan sebagai sebuah panduan awal yang dapat ditindaklanjuti secara lebih lanjut.

\section{Metode}

Metode penelitian yang diterapkan dalam penelitian ini adalah metode penciptaan karya seni, yang merupakan sebuah metode yang lazim dipergunakan dalam penciptaan karya seni rupa pada umumnya. Dalam tahapan pelaksanaannya, metode penciptaan ini kemudian dapat dibagi menjadi tiga tahapan utama sebagai berikut.

\section{Tahap Eksplorasi}

Tahap eksplorasi merupakan sebuah tahap awal yang dilaksanakan guna menggali data yang diperlukan. Kegiatan ini dilakukan dengan metode studi pustaka, observasi, dan wawancara.

Studi pustaka adalah kegiatan pengumpulan data khususnya tentang seluk-beluk tie-dye, khususnya yang berkenaan dengan aspek teknik dan motif yang dihasilkan. Kegiatan pengumpulan data ini dilakukan dengan cara mengunjungi berbagai perpustakaan, yaitu perpustakaan di beberapa perguruan tinggi yang dianggap representatif, perpustakaan di wilayah kota Yogyakarta seperti perpustakaan Balai Kajian Jarahnitrah, perpustakaan Museum Negeri Sonobudoyo Yogyakarta, perpustakaan Kolese St. Ignatius, perpustakaan kota Yogyakarta, perpustakaan Balai Penelitian Batik dan Kerajinan, perpustakaan Keraton Yogyakarta, dan perpustakaan lain yang dipandang relevan dengan topik penelitian. Data ini juga dapat diperoleh melalui internet guna menambah pengayaan dan perbendaharaan data. Data yang diperoleh dari studi pustaka ini berupa data tertulis maupun data visual berupa gambar atau foto dari berbagai sumber pustaka, baik yang tertuang dalam buku-buku terbitan, majalah, laporan penelitian, artikel, dan publikasi ilmiah lainnya.

Observasi adalah kegiatan
pengamatan secara langsung terhadap
objek penelitian yang meliputi berbagai
produk tie-dye yang dipasarkan di wilayah
kota Yogyakarta. Observasi dilakukan di
lokasi penjualan atau pemasaran produk
tie-dye di wilayah ini yang dipandang
representatif, yaitu di kawasan Malioboro


dan Pasar Beringharjo, yang kebetulan di kedua lokasi tersebut sekaligus merupakan objek wisata utama di kota Yogyakarta. Observasi meliputi jenis produk busana (fashion) dan perlengkapannya, produk interior dan perlengkapannya, asesoris hingga cinderamata. Kegiatan ini dilakukan guna mendapatkan gambaran secara kongkrit tentang objek-objek tersebut. Bersamaan dengan kegiatan observasi, sudah barang tentu dilakukan kegiatan pendokumentasian / pengambilan gambar / foto dari objek-objek tersebut.

Wawancara dilakukan kepada para narasumber yang dianggap mampu memberikan penjelasan tentang objek yang diteliti. Dari kegiatan ini didapatkan data lisan yang dapat dimanfaatkan untuk melengkapi data tertulis, data foto, maupun data gambar hasil dari kegiatan studi pustaka dan observasi di lapangan.

Penelitian ini menerapkan analisis deskriptif. Seluruh data tertulis dan lisan yang diperoleh melalui studi pustaka dan wawancara disajikan dalam bentuk uraian. Sementara itu data yang berupa gambar atau foto disajikan dalam bentuk data visual. Seluruh data yang berhasil dikumpulkan tersebut kemudian dianalisis untuk selanjutnya dijadikan acuan dasar dalam proses perancangan motif tie-dye.

\section{Tahap Perancangan}

Tahap perancangan adalah tahap pembuatan motif tie-dye yang dilaksanakan melalui beberapa langkah, yaitu: (a) proses pembuatan sket alternatif; (b) pemilihan sket alternatif; (c) pembuatan desain jadi; dan (d) tahap eksperimen.

\section{Tahap Perwujudan}

Tahap perwujudan merupakan tahap mewujudkan desain jadi menjadi sejumlah prototip motif tie-dye yang diwujudkan di atas kain.

\section{Hasil dan Pembahasan}

\section{a. Tie-dye di Kota Yogyakarta}

Berdasarkan observasi lapangan yang telah dilakukan terhadap berbagai macam jenis produk tie-dye yang dipasarkan di dua lokasi utama, yaitu di pasar Beringharjo Yogyakarta maupun kawasan Malioboro Yogyakarta sebagai sampel terpilih, maka dapat diidentifikasikan menjadi beberapa jenis produk, yaitu produk busana, perlengkapan busana, perlengkapan interior, dan cinderamata.

Berdasarkan data yang telah diperoleh, maka dapat diidentifikasikan, bahwa produk-produk tie-dye yang dipaskan di kota Yogyakarta dapat dibedakan menjadi berbagai macam jenis produk, yaitu meliputi produk busana yaitu berupa kaos (baik berlengan maupun tanpa lengan), dhaster, pakaian anak-anak, wanita, dan lain sebagainya. Produk cinderamata di antaranya berupa syal (scarf), slayer, dan kain pantai. Pada produk busana tidak hanya diwujudkan dengan teknik tie-dye saja, namun sudah nampak dipadukan dan dikombinasikan dengan teknik batik dan payet (aplikasi).

Untuk penerapan terknik ditemukan beberapa keteknikan yang lazim dijumpai pada keteknikan dalam jumputan, 
tritik, dan pelangi seperti teknik, tie (ikat) dan stitch (jahit) . Teknik yang paling banyak dijumpai adalah teknik stitch (jahit) yang diterapkan pada produk busana dan perlengkapan interior hingga pada produk cinderamata. Teknik stitch (jahit) banyak diterapkan pada hampir semua produk dikarenakan melalui teknik ini mampu mewujudkan berbagai motif dengan bentuk yang persis atau mendekati garis rancangan. Teknik stitch (jahit) juga menghasilkan motif yang dapat diprediksikan hasilnya, meskipun terkadang juga timbul efek tidak terduga dari penerapan teknik ini. Di samping teknik stitch (jahit), teknik fold (simpul) juga nampak banyak diterapkan. Teknik fold (simpul) sebenarnya merupakan hasil pengembangan dari teknik pleat (lipat) yang kemudian dikombinasikan dengan teknik pengikatan pada bagian penampang kain. Teknik fold (simpul) dapat menghasilkan motif repetisi atau pengulangan dengan bentuk yang simetris berupa motif-motif berupa garis lurus. Teknik kerut merupakan sebuah teknik yang cukup sederhana dan cepat di dalam pembentukan sebuah motif di atas kain. Sementara itu teknik tie (ikat) meskipun merupakan keteknikan paling mendasar dalam tie-dye namun teknik ini kebanyakan hanya diterapkan pada produkproduk yang berharga relatif murah yang hanya membutuhkan penerapan motif yang sederhana. Teknik tie (ikat) ini kalau di Jawa termasuk di kota Yogyakarta dikenal sebagai teknik jumputan, karena di dalam mewujudkannya ditempuh dengan cara menjumput atau mencubit kain kemudian diikat. Seringkali untuk memudahkan proses pengikatan kadang-kadang dibantu dengan biji-bijian seperti kacang hijau, jagung, termasuk kerikil dan lain sebagainya. Teknik pleat (lipat) meskipun juga banyak diterapkan, namun umumnya tidak berdiri sendiri atau biasanya dikombinasikan dengan teknik lainnya. Teknik-teknik lain seperti marbling (marmer), knot (kancing), dan roll (gulung) yang dikenal sebagai bagian dari keteknikan dalam shibori, nampak belum banyak diterapkan apalagi dikembangkan secara lebih lanjut,

Teknik pewarnaan yang paling banyak diterapkan pada hampir semua produk adalah teknik dye (celup) sebagai teknik paling mendasar dan paling konvensional di dalam memberi warna pada kain. Di samping mudah, teknik ini juga mampu menghasilkan warna yang merata. Teknik tuang juga cukup banyak diterapkan, yaitu pewarnaan dengan cara menuangkan atau menyiramkan secara langsung bahan warna di atas kain menggunakan jenis warna yang beraneka macam atau multicoloured dan biasanya bergradasi antara satu warna dengan warna lainnya. Teknik colet nampak pula cukup banyak diaplikasikan karena secara teknis proses pewarnaan dengan jalan dikuaskan ini sangat praktis dan dapat menghasilkan warna yang beranekaragam sesuai keinginan pembuatnya. Ada pula teknik pewarnaan dengan cara disemprot (spray) sebagai sebuah teknik hasil pengembangan teknik yang sudah ada sebelumnya. Belum nampak banyak dijumpai penerapan teknik tabur pada produk-produk yang dipasarkan di kota Yogyakarta. Diduga penerapan teknik tabur ini cenderung kurang ekonomis karena membutuhkan bahan warna yang cukup banyak.

Motif-motif yang ditampilkan pada berbagai macam produk tersebut umumnya adalah motif geometris. Motif geometris 
merupakan motif yang paling banyak diterapkan karena memang relatif mudah untuk diwujudkan. Belum banyak dijumpai penerapan motif flora maupun fauna pada produk. Motif-motif flora dan fauna memang lebih sulit diwujudkan dengan teknik-teknik dalam tie-dye. Hal ini dikarenakan dibutuhkan ketepatan, kecermatan, dan penguasaan di dalam penerapan segala aspek terutama teknik yang diterapkan dan alat serta bahan yang dipergunakan.

Berdasarkan identifikasi di atas, maka pengembangan teknik dan motif tiedye pada produk tie-dye yang dipasarkan di kota Yogyakarta dapat ditempuh dengan cara menerapkan kombinasi dan memadupadankan teknik yang sudah ada dengan teknik-teknik yang belum begitu banyak diterapkan. Dengan demikian akan diperoleh sebuah perwujudan motif yang lebih bervariasi dan menarik.

\section{b. Tahap Perancangan dan Perwujudan}

Proses penciptaaan motif tie-dye dalam penelitian ini diawali dengan pembuatan sejumlah sket alternatif guna menciptakan 20 motif tie-dye yang baru. Masing-masing dari motif tersebut, pada awalnya terlebih dahulu dibuatkan sket alternatifnya. Berdasarkan sejumlah sket alternatif tersebut kemudian dipilih salah satu untuk disempurnakan atau dibuat menjadi gambar jadi. Pembuatan sket alternatif ini dimaksudkan untuk mencari berbagai kemungkinan terciptanya motif yang menarik dengan berbagai pilihan.
Langkah awal yang dilakukan dalam proses pembuatan sket alternatif ini adalah membuat gambar motifnya terlebih dahulu. Gambar motif dibuat terutama berdasarkan data visual berupa foto. Data yang ada di foto tersebut kemudian diolah dan divisualisasikan kembali hingga menjadi gambar motif yang cocok untuk diterapkan dengan keteknikan dalam tie-dye. Motif yang sudah terwujud, selanjutnya disusun hingga menjadi suatu pola tertentu. Motif tie-dye disusun dengan cara bervariasi, di antaranya dengan mengulangnya secara teratur di atas bidang gambar, yang dibagi menjadi bidang-bidang yang teratur pula.

Di dalam sket alternatif dibuat dengan mempertimbangkan berbagai aspek, antara lain bahan warna yang dipergunakan, teknik, maupun proses perwujudnya. Selain itu juga dengan memperhatikankan prinsip-prinsip desain yang meliputi irama/ritme/keselarasan, kesatuan, dominasi/daya tarik/pusat perhatian/keunikan, keseimbangan, proporsi/perbandingan/keserasian, kesederhanaan dan kejelasan. Dengan memperhatikan kaidah-kaidah tersebut, maka diharapkan akan tercipta motif tiedye yang estetis, eksploratif, dan inovatif. Sejumlah sket alternatif yang telah dibuat dari masing-masing motif kemudian dipilih dan diseleksi salah satu yang dianggap paling bagus.

Pembuatan motif tie-dye seluruhnya dikerjakan secara manual. Sket yang terpilih kemudian disempurnakan hingga menjadi gambar jadi pola motif tiedye, di atas kertas dengan ukuran $30 \times 30$ $\mathrm{cm}$. Tahap atau langkah pengerjaannya yaitu menyempurnakan garis gambar motif 
secara manual berdasarkan sket alternatif terpilih sehingga terciptalah gambar motif tie-dye.

Peralatan yang digunakan dalam membuat tie-dye dapat dikategorikan menjadi dua, yaitu alat untuk proses tie (pengikatan) dan proses dye (pewarnaan). Ada banyak peralatan yang dapat dikembangkan dalam pembuatan tie-dye, bahakan seringkali peralatan sederhana yang berasal dari benda yang sederhana dan kelihatannya tidak berguna dapat pula dimanfaatkan.

\section{Alat-alat untuk proses tie (pengikatan)}

Prinsipnya alat yang digunakan untuk mengikat adalah alat yang berupa tali atau benang yang berbahan sintetis, ataupun serat yang memiliki kekuatan dan daya tahan untuk melindungi kain secara baik terhadap penyerapan warna dalam proses pewarnaan. Alat-alat yang biasa digunakan adalah tali plastik (raffia), tali jemuran (tali tampar), senar, tali berbahan karet seperti kolor, tali dari bahan ban bekas yang dipotong-potong memanjang, karet gelang, berbagai jenis benang sintetis (biasanya benang jeans), berbagai macam serat atau tali seperti agel, serat pisang, pandan, dan eceng gondok, jarum jahit untuk teknik stitch (jahit). Kemudian berbagai macam plastik, baik kantong plastik, tas plastik, plastik lembaran yang memiliki sifat elastis yang baik, dan lain sebagainya.

Di samping itu ada pula alat-alat sebagai peralatan bantu untuk mempermudah dalam proses pengikatan dalam teknik yang dikenal dengan nama jumputan, yaitu biji-bijian (misalnya dari jagung, kacang, hijau, kedelai dan beras), kelereng, kerikil, berbagai macam jenis manik-manik termasuk kancing baju juga bisa dimanfaatkan, kemudian alat-alat untuk teknik press (tekan) dan pleat (lipat), yaitu potongan-potongan kayu/balok atau bambu, jepitan jemuran dari plastik, dan setrika (sebagai alat untuk merapikan hasil lipatan), alat-alat untuk teknik roll (gulung), yaitu pipa pralon dari plastik, batang bambu, botol, dan lain sebagainya.

\section{Alat-alat untuk proses dye (pewarnaan)}

Alat-alat untuk proses pewarnaan, yaitu ember dari bahan plastik, kaca atau keramik (untuk teknik celup), semprotan dari plastik (tudor) digunakan untuk teknik spray (semprot), botol bekas aki atau cuka untuk teknik tuang, kuas (jegol), busa (spons) untuk teknik colet dan usap, dan saringan teh untuk teknik tabur. Berbagai macam peralatan tersebut di atas hanyalah contoh peralatan yang bisa digunakan dalam membuat tie-dye. Peralatan tersebut dapat dikembangkan lagi sesuai kreativitas si pembuatnya.

Yang dimaksud dengan bahan pembuatan tie-dye adalah bahan berupa kain dan bahan pewarna.

1. Kain

Umumnya semua jenis kain bisa dipergunakan untuk pembuatan produk tiedye, baik dari bahan alam maupun bahan sintetis. Kain dari bahan alam yaitu berbagai macam kain katun seperti berkoline, prima, primissima, voalissima, grey (blaco), kemudian santung, linen, sutera, dan lain sebagainya. Bahan baku yang dipergunakan untuk membuat kain tie-dye dalam penelitian ini adalah kain dari jenis primissima. Dipilihnya jenis primissima ini 
karena jenis kain primissima merupakan salah satu dari beberapa macam jenis kain yang terbuat dari bahan kapas, dan merupakan jenis kain mori dengan tingkatan yang paling halus dan memiliki tingkat kenyamanan yang baik, sehingga dipandang cocok dan sesuai jika difungsikan sebagai bahan sandang. Biasanya kain dari jenis primissima ini juga dipergunakan sebagai bahan baku batik tulis halus ataupun batik cap dengan tingkatan atau kualitas yang halus pula. Sudah barang tentu dengan dipergunakannya bahan baku dengan kualitas yang baik ini, maka diharapkan akan dapat menghasilkan karya jadi berupa kain batik dengan mutu dan tingkatan kualitas yang tinggi pula. Kain primissima ini di pasaran biasa diperdagangkan dalam bentuk piece (blok, geblok, gulungan) dengan ukuran lebar sekitar $106 \mathrm{~cm}$ dan panjang sekitar 15,5 m. Mori jenis ini mengandung kanji dalam ukuran yang ringan, rata-rata hanya berkisar 4\%, sehingga kandungan kanji di dalamnya mudah untuk dihilangkan dalam proses pencucian (Susanto, 1980: 54). Kain dari jenis primissima ini dapat langsung dipergunakan untuk membuat kain batik tanpa didahului dengan persiapan kain secara khusus. Akan tetapi sebaiknya sebelum dibatik, kain ini perlu dicuci terlebih dahulu, agar bahan warna yang diterapkan dapat meresap dengan lebih baik dan sempurna ke dalam serat kain.

\section{Bahan warna}

Untuk bahan warna dipergunakan bahan warna sintetis dari jenis naphtol dan indigosol. Zat warna naphtol adalah bahan pewarna batik yang terdiri dari dua bagian atau komponen utama, yaitu naphtol sebagai dasar warna dan garam diazo sebagai pembangkit warna. Agar zat warna naphtol ini dapat dipergunakan atau diterapkan pada kain, maka terlebih dahulu harus dicampur dengan bahan bantu berupa TRO dan kostik soda terlebih dahulu. Lazimnya, zat warna naphtol ini dipergunakan untuk teknik celup.

Resep umum zat warna naphtol:

1 liter air: 3-4 gram naphtol

TRO $2 \times$ cat

Kostik soda (loog 38 Be) 2 x cat

Garam diazo 2-3 x cat (Susanto, 1980: 87).

Zat warna indigosol adalah zat warna batik yang biasanya diterapkan untuk proses pewarnaan dengan teknik celup dan colet. Beberapa jenis warna indigosol akan timbul warnanya setelah terpapar oleh sinar matahari (ultraviolet), kemudian dioksidisasi atau dikunci dengan natrium nitrit dan asam chlorida sebagai bahan pembangkit atau pengunci warna.

Resep untuk zat warna indigosol dengan teknik celup:

1 liter air: 2-3 gram cat indigosol.

10-20 cc asam chlorida

3-5 gram nitrit (1-1,5 $\times$ cat)

Resep untuk zat warna indigosol teknik colet:

8 gram indigosol/100 cc larutan (Susanto, 1980: 89-90). 


\section{Simpulan}

Berbagai macam jenis dan produk tie-dye yang dipasarkan di kota Yogyakarta sebagian sudah cukup beragam baik dari aspek bentuk, fungsi, maupun motif yang diterapkan. Kombinasi dengan keteknikan lain seperti batik dan aplikasi payet juga sudah nampak dilakukan. Umumnya produk yang sudah ada masih menggunakan beberapa teknik konvensional yang dikenal sebagai jumputan, tritik, dan pelangi. Berdasarkan analisis, maka pengembangan dapat dilakukan pada beberapa aspek yang meliputi teknik, baik teknik pengikatan maupun teknik pewarnaan, motif, alat, bahan, serta bentuk dan jenis produknya. Pengembangan dapat dilakukan dengan mengkombinasikan teknik konvensional dengan teknik-teknik yang sudah dimodifikasi dalam satu proses perwujudan. Dari keteknikan dasar, maka berbagai teknik dalam tie-dye dapat dikombinasikan, dikembangkan, serta dieksplorasi secara terus-menerus secara tidak terbatas. Aspek pengembangan di samping desain pada motif, juga pada eksplorasi alat dan bahan, mengingat peralatan untuk mewujudkan karya tie-dye sangat beragam dan sangat bisa dikembangkan secara lebih lanjut. Hal ini dikarenakan motif yang dapat dihasilkan memiliki berbagai variasi efek yang bernilai artistik tinggi, seringkali tak terduga dapat muncul atau dimunculkan begitu saja, bahkan dapat terwujud tanpa unsur kesengajaan di dalam mewujudkannya.

\section{Daftar Pustaka}

Djoemena, Nian S., 1990, Batik dan Mitra: Batik and its Kind, Jakarta: Djambatan.
Joanifer Gibbs, 1974, Batik Unlimited, Watson-Guptill Publications, London: New York Pitman Publishing, Keller, Ila, Batik The Art and Craft, 1971, Tokyo: Charles E. Tuttle Company Publishers Rutland, Vermont.

Susanto, S.K., 1980, Seni Kerajinan Batik Indonesia, Yogyakarta: Balai Penelitian Batik dan Kerajinan, Lembaga Penelitian dan Pendidikan Industri Departemen Perindustrian RI.

Wada, Yoshiko Iwamoto, Kellogg Rice, Mary, and Barton, Jane, 1999, Shibori:

The Inventive Art of Japanese Shaped Resist Dyeing: Tradition Techniques Inovation, Tokyo: Kodansha International Ltd.

Widodo, Suryo Tri, 2012, Kriya Tekstil Tie-Dye (Ikat Celup): Sebuah Media Eksplorasi Estetis Yang

Populer. Corak: Jurnal Seni Kriya, Vol. 1 No 2, November 2012, Yogyakarta: Penerbit Jurusan Kriya Fakultas Seni Rupa ISI Yogyakarta. 2010, Pengembangan Teknik dan Motif pada Produk Tie-Dye (Ikat Celup) di Kota Yogyakarta. Laporan Penelitian tidak diterbitkan, Yogyakarta: Lembaga Penelitian Institut Seni Indonesia Yogyakarta.

1998, Kriya Tekstil Tie-Dye di ARIMBI Fashion Design \& Production Exclusive Tie \& Dye. Skripsi tidak diterbitkan, Yogyakarta: Program Sarjana Institut Seni Indonesia Yogyakarta, 


\section{Lampiran}

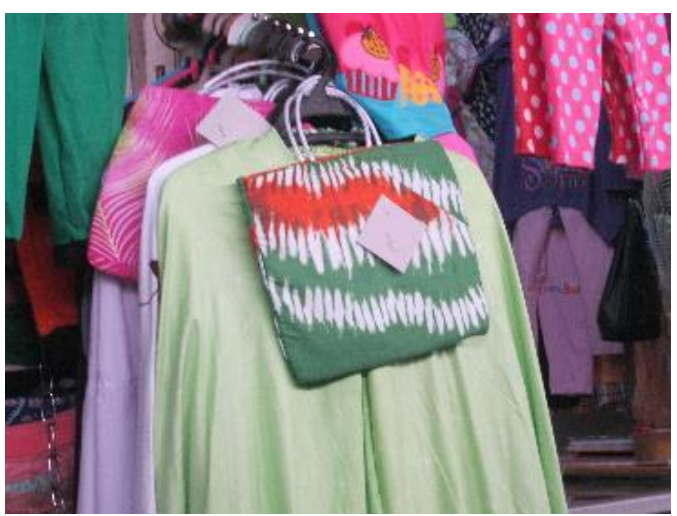

Gambar 1. Tas wanita (lokasi: pasar Beringharjo Yogyakarta)

a. Teknik pengikatan: teknik stitch (jahit).

b. Teknik pewarnaan: teknik dye (celup) dan colet menggunakan dua warna, yaitu hijau dan oranye.

c. Motif: lengkung yang tersambung dan bersusun membentuk seperti ombak.

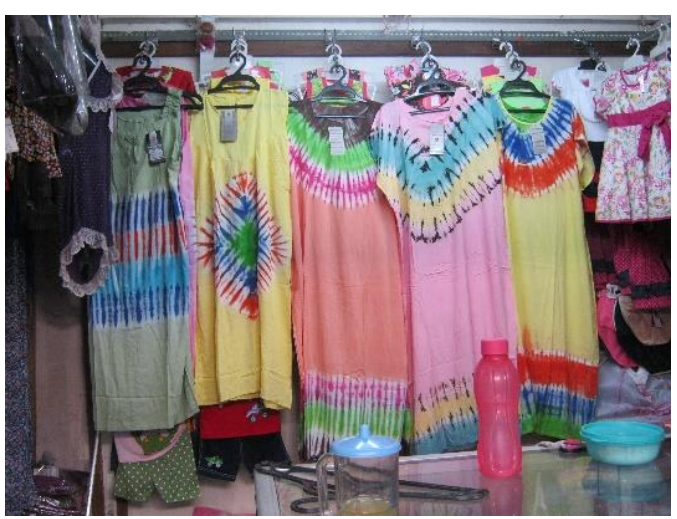

Gambar 2. Busana wanita (dhaster) (lokasi: pasar Beringharjo Yogyakarta)

a. Teknik pengikatan: stitch (jahit).

b. Teknik pewarnaan: teknik spray (semprot), colet, dan tuang menggunakan banyak warna (multi coloured).

c. Motif: kombinasi persegi, lengkung, dan garis lurus sejajar.

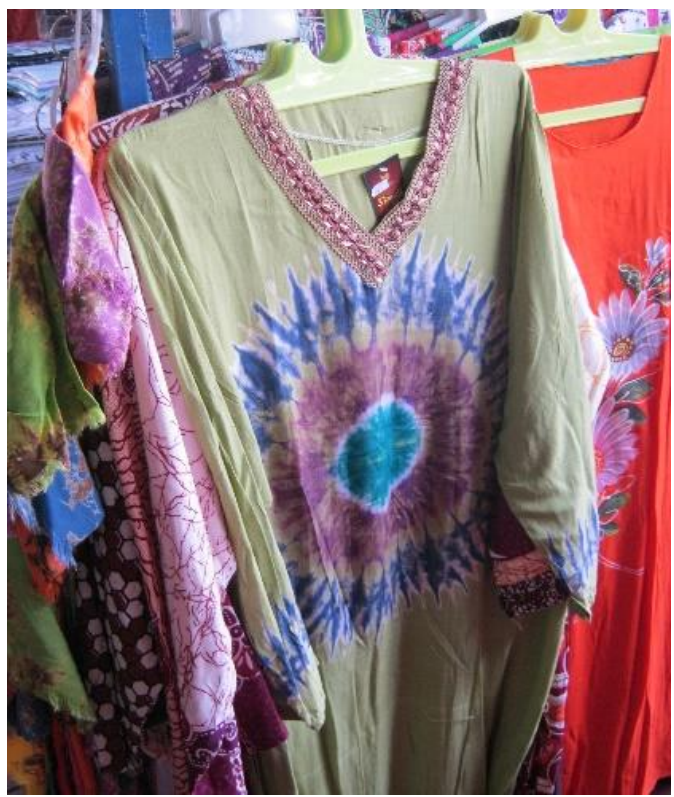

Gambar 3. Busana tidur wanita (lokasi: Malioboro Yogyakarta)

a. Teknik pengikatan: teknik tie (ikat) dikombinasikan dengan stitch (jahit).

b. Teknik pewarnaan: teknik tuang menggunakan warna hijau, ungu, dan biru.

c. Motif: lingkaran yang memusat ke satu titik bidang berbentuk belah ketupat.

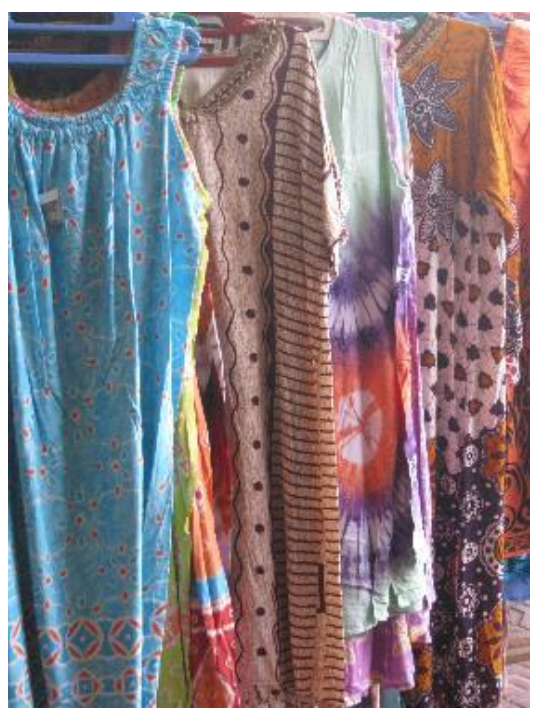

Gambar 4. Busana wanita (dhaster) (lokasi: Malioboro Yogyakarta) 
a. Teknik pengikatan: teknik tie (ikat) dan stitch (jahit)

b. Teknik pewarnaan: teknik tuang menggunakan banyak warna (multi coloured).

c. Motif: kombinasi lingkaran dan garis lengkung

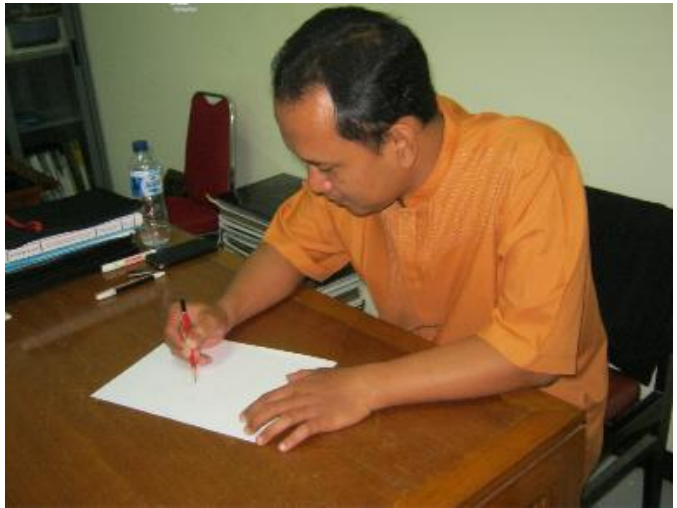

Gambar 5. Pembuatan sket alternatif/ Perancangan motif tie-dye

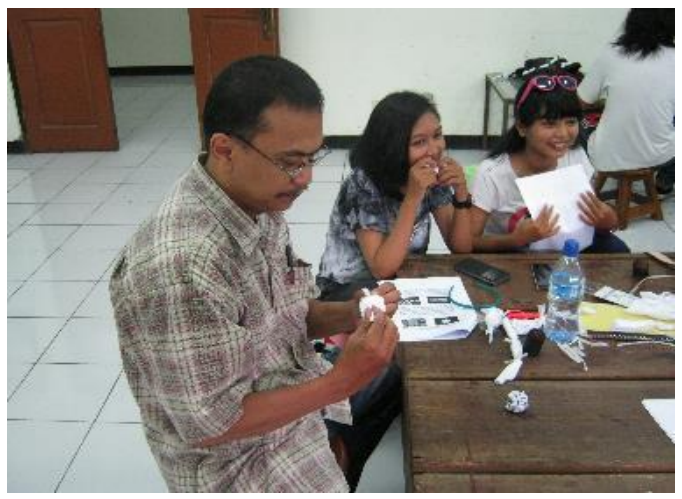

Gambar 6. Proses pengikatan

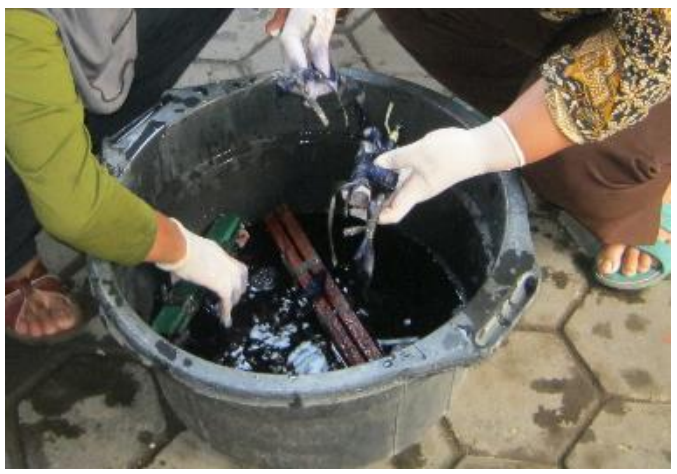

Gambar 7. Proses pewarnaan

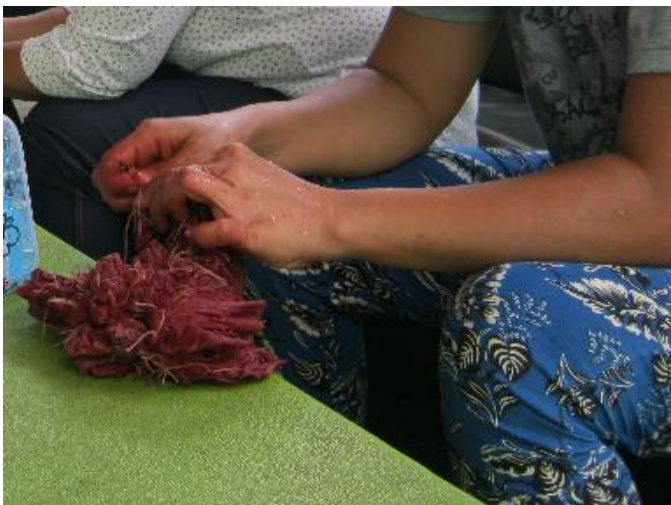

Gambar 8. Proses membuka ikatan

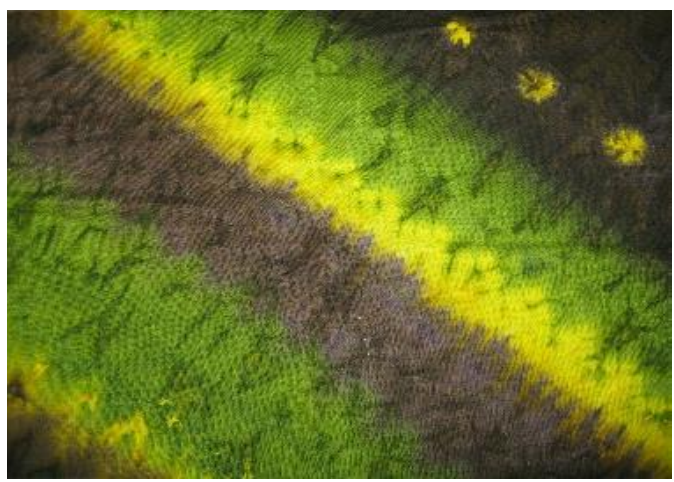

Gambar 9. Prototip 1

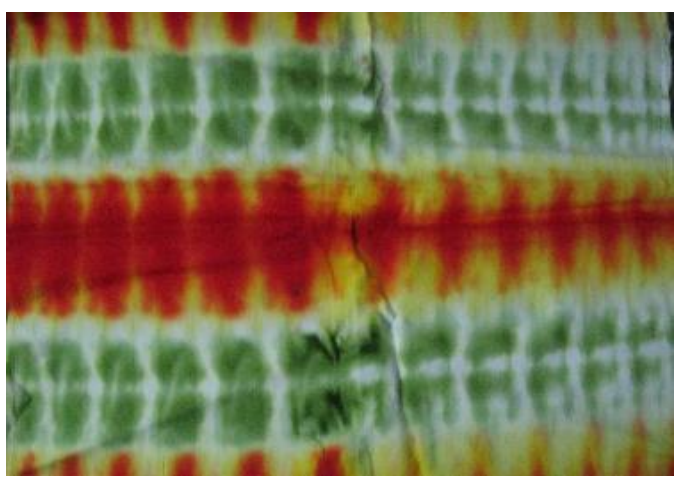

Gambar 10. Prototip 2

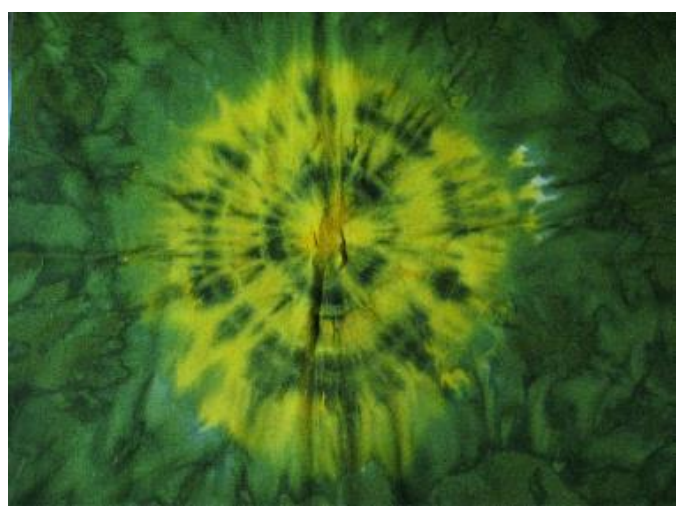

Gambar 11. Prototip 